\title{
Effectiveness of a Complex Fertilisation Technology Applied to Zea mays, Assessed Based on Normalised Difference Vegetation Index (NDVI) from Terra Moderate Resolution Imaging Spectroradiometer (MODIS)
}

\author{
Natalia Matłok ${ }^{1, *(\mathbb{D}}$, Oskar Basara ${ }^{1}$, Miłosz Zardzewiały ${ }^{1} \mathbb{D}$, Józef Gorzelany ${ }^{1}$ and Maciej Balawejder ${ }^{2} \mathbb{D}$ \\ 1 Department of Food and Agriculture Production Engineering, University of Rzeszow, St. Zelwerowicza 4, \\ 35-601 Rzeszów, Poland; oskarbasara@gmail.com (O.B.); mzardzewialy@ur.edu.pl (M.Z.); \\ gorzelan@ur.edu.pl (J.G.) \\ 2 Department of Chemistry and Food Toxicology, University of Rzeszow, St. Ćwiklińskiej 1a, \\ 35-601 Rzeszów, Poland; maciejb@ur.edu.pl \\ * Correspondence: nmatlok@ur.edu.pl
}

check for updates

Citation: Matłok, N.; Basara, O.;

Zardzewiały, M.; Gorzelany, J.;

Balawejder, M. Effectiveness of a Complex Fertilisation Technology Applied to Zea mays, Assessed Based on Normalised Difference Vegetation Index (NDVI) from Terra Moderate Resolution Imaging Spectroradiometer (MODIS). Agriculture 2021, 11, 754. https://doi.org/10.3390/ agriculture11080754

Academic Editor: Surya Kant

Received: 14 July 2021

Accepted: 6 August 2021

Published: 8 August 2021

Publisher's Note: MDPI stays neutral with regard to jurisdictional claims in published maps and institutional affiliations.

Copyright: (c) 2021 by the authors. Licensee MDPI, Basel, Switzerland. This article is an open access article distributed under the terms and conditions of the Creative Commons Attribution (CC BY) license (https:// creativecommons.org/licenses/by/ $4.0 /)$.

\begin{abstract}
Assessment of effectiveness of fertilisation is a complex, multistage procedure. A few methods, used for this purpose, are based mainly on physiological measures acquired from a limited number of plants. Assessment of the process taking into account the entire area, in which the crop is grown, can be conducted using satellite remote sensing methods. The current study presents four fertilisation schemes applied to maize plants, including innovative foliar fertilizers and soil localized fertilization. Nutritional status and condition of the plants were assessed using Normalized Difference Vegetation Index (NDVI), and the results were analysed in relation to the grain yield. The findings show that the complex fertilisation technology applied to maize is most effective, producing grain yield which was $42.4 \%$ higher than the yield from the control variant.
\end{abstract}

Keywords: maize; fertilisation; satellite remote sensing; NDVI; growing degree days (GDD)

\section{Introduction}

Advancements in agriculture are associated with increasing consumption of energy and materials necessary for production, such as mineral fertilisers, chemical crop protection agents, as well as operation of machines. The related practices result from the globally growing demand for food and raw materials; however, they also adversely affect the natural environment, by polluting water and soil, and damaging soil fertility [1,2]. To ensure both people's food security and environment preservation, it is necessary to introduce new solutions in crop production [3]. These include precision agriculture which enables changes in the production of food and raw materials [4].

Today large farms specializing in crop production may employ smart solutions-such as geographic information system (GIS), global positioning system (GPS), computer-aided modelling, and satellite remote sensing-which enable timely crop management during the growth season and off-season [5]. Remote sensing systems applied in precision agriculture make it possible to identify the nutritional status of plants, as well as diseases, pests and weeds affecting the crops. The remote sensing technology allows producers to acquire information about the growing crops without a need to use any vehicles which may damage the plants. Owing to such data, it is possible to evaluate the health indicators of the plants or apply fertilizers and plant protection products only in places where there is a need for interventions [6].

The indicators determined using satellite remote sensing method include the Normalized Difference Vegetation Index (NDVI), which is most commonly applied in accessing crop production [7]. NDVI is a simple numerical indicator and a tool enabling assessment 
of changes taking place in green plants [8]. It is also used to estimate the biomass yield [9]. NDVI can also be used to determine nitrogen contents in plants [10], based on which it is possible to define optimum dosing of nitrogen fertilisers [11]. Moreover, the indicator is applied to evaluate effects of water stress on plants during vegetation [12] and to assess harvest maturity in crops [13]. Furthermore, Vegetation Condition Index (VCI) can be calculated from NDVI. The related calculations are based on NDVIs recorded over a number of years [14]. Another indicator used in crop production is the Temperature Condition Index (TCI). It is determined based on satellite images and is used to assess drought severity. TCI provides information about availability of water to plants [15]. The plant, with sufficient access to water, evaporates the moisture, thus regulating the temperature. When water resources are limited, evaporation decreases and the temperature on the surface of the plants increases. Based on the amount of infrared radiation emitted by the plants and recorded by satellites it is possible to determine the parameters of TCI [16].

Satellite systems used in precision agriculture beneficially affect profitability of farming operations, productivity, quality of crops, environment protection, and quality of life in rural areas. Precision agriculture was introduced to increase effectiveness of resource use and to limit inefficient decisions in farm management [4].

The present study assessed effectiveness of a complex new fertilisation technology applied to Zea mays L., based on innovative foliar and soil localized fertiliser produced from calcinated bones. The Normalised Difference Vegetation Index (NDVI) from Terra Moderate Resolution Imaging Spectroradiometer (MODIS) was utilized to confirm effectiveness of fertilisation.

\section{Materials and Methods}

\subsection{Characteristics of the Applied Fertilisers}

Two innovative fertilisers, applied in the process of maize cultivation, contained mineral components obtained as a result of thermal treatment of bone waste. Foliar fertiliser (Fertiliser 1) was produced by separating soluble mineral compounds with the use of nitric acid solution (V), and by adding boric acid and molybdenum compounds [17]; the resulting fertiliser had the following content: $48.8 \mathrm{P}\left(\mathrm{g} \mathrm{kg}^{-1}\right), 12.5 \mathrm{~N}\left(\mathrm{~g} \mathrm{~kg}^{-1}\right), 1.2 \mathrm{~K}\left(\mathrm{~g} \mathrm{~kg}^{-1}\right)$, 4.4 Mg $\left(\mathrm{g} \mathrm{kg}^{-1}\right), 80.3 \mathrm{Ca}\left(\mathrm{g} \mathrm{kg}^{-1}\right), 4.2 \mathrm{Na}\left(\mathrm{g} \mathrm{kg}^{-1}\right), 70 \mathrm{~B}\left(\mathrm{~g} \mathrm{~kg}^{-1}\right), 2 \mathrm{Mo}\left(\mathrm{g} \mathrm{kg}^{-1}\right), 10 \mathrm{Fe}\left(\mathrm{mg} \mathrm{kg}^{-1}\right)$, $8 \mathrm{Zn}\left(\mathrm{mg} \mathrm{kg}^{-1}\right)$, and $1.5 \mathrm{Cu}\left(\mathrm{mg} \mathrm{kg}^{-1}\right)$ [18]. All the nutrients are contained in the fertiliser in their soluble forms therefore they are easily available to plants.

The fertiliser for precision application, with controlled release of the components (Fertiliser 2), was produced through micronisation of thermally processed bone waste to particle size $<150 \mu \mathrm{m}$, followed by addition of lake chalk and whey protein isolate in the proportions 79:19:2 $w / w$ [19]. The resulting fertiliser had the following content: $136.81 \mathrm{P}\left(\mathrm{g} \mathrm{kg}^{-1}\right)$, $3.2 \mathrm{~N}\left(\mathrm{~g} \mathrm{~kg}^{-1}\right), 29.96 \mathrm{~K}\left(\mathrm{~g} \mathrm{~kg}^{-1}\right), 13.20 \mathrm{Mg}\left(\mathrm{g} \mathrm{kg}^{-1}\right), 347.81 \mathrm{Ca}\left(\mathrm{g} \mathrm{kg}^{-1}\right), 3.93 \mathrm{Na}\left(\mathrm{g} \mathrm{kg}^{-1}\right)$, $1 \mathrm{Fe}\left(\mathrm{g} \mathrm{kg}^{-1}\right), 0.8 \mathrm{Zn}\left(\mathrm{mg} \mathrm{kg}^{-1}\right), 3.2 \mathrm{Cu}\left(\mathrm{mg} \mathrm{kg}^{-1}\right)$, and $6.5 \mathrm{Mn}\left(\mathrm{mg} \mathrm{kg}^{-1}\right)$ [18]. Microgranule for precision application is distinguished by a well-proven mechanism enabling controlled release of ammonia nitrogen and amino acids during hydrolysis of protein additive [20].

\subsection{Description of the Field Experiments}

The field experiment (covering a large area of $109.71 \mathrm{ha}$ ), designed to assess effects of the proposed fertilisation technologies on the growth and yield of maize, was conducted in 2019, on loamy sand soil. Maize was the forecrop in the experiment. In the autumn, based on its composition, the soil was fertilized with Holist ${ }^{\circledR}$ agro PK 15-30 (Grupa Azoty Puławy, Puławy, Poland), a dose of $200 \mathrm{~kg} \mathrm{ha}^{-1}$ and with cattle manure, a dose of $25 \mathrm{tha}^{-1}$. In the spring, pre-sowing fertilisation was applied: MAGSUL (Mg S 18-38; CHEMIROL sp. z o.o., Mogilno, Poland) and RSM N32 $190 \mathrm{~kg} \mathrm{ha}^{-1}$ (Grupa Azoty Puławy, Puławy, Poland). The applied fertilisers were characterised in Supplementary Materials (S1). Maize of moderately early maturing variety Pioneer (P8589; FAO K250, Z250) (Pioneer Hi-Bred Poland Sp. z o.o., Warszawa, Poland) was planted on 14 April. Seeding density of $85,000 / \mathrm{ha}^{-1}$, and seeding 
depth of $5 \mathrm{~cm}$ were applied. Weed control was ensured by applying Maister Power 42.5 OD, with dosing of $0.751 \mathrm{ha}^{-1}$ (Bayer Sp. z o. o., Warszawa, Poland). In all the experimental variants, foliar fertiliser Dr. Green Kukurydza containing microelements was applied at a dose of $3 \mathrm{~kg} \mathrm{ha}^{-1}$ (quantity of working liquid $2001 \mathrm{ha}^{-1}$ ) (Dr. Green Sp. z o.o., Chrzanów, Poland). The microelements were applied at air temperature of $22{ }^{\circ} \mathrm{C}$, during the six-leaf stage of maize growth (BBCH 16), using a self-propelled sprayer Tecnoma LASER 4000 (Rue Marcel Paul, Épernay, France).

Maize was harvested on 9 October, with New Holland CX880 (New Holland Agriculture, PA, USA).

The field covering an area of 109.71 ha was divided into four parts, where the following fertilisation schemes were tested:

F0—control;

F1-foliar fertilisation-Foliar Fertilizer Based on Calcined Bones, Boron and Molybdenum (Fertiliser 1), with dosing of $3 \mathrm{~kg} \mathrm{ha}^{-1}$ (quantity of working liquid $2001 \mathrm{ha}^{-1}$ ), applied jointly with microelement fertiliser (BBCH 16);

F2-soil amendment-microgranules for precision application into the soil (Fertiliser 2), with dosing of $30 \mathrm{~kg} \mathrm{ha}^{-1}$. Application, concurrent with maize seed planting, at a depth of $7 \mathrm{~cm}$;

F3 - complex technology—combined use of microgranules for precision application into the soil (Fertiliser 2, dose of $30 \mathrm{~kg} \mathrm{ha}^{-1}$, (application, concurrent with maize seed planting, at a depth of $7 \mathrm{~cm}$ ) as well as the foliar fertiliser (Fertiliser 1, a dose of $3 \mathrm{~kg} \mathrm{ha}^{-1}$, application during $\mathrm{BBCH} 16$ phase).

\subsection{Satellite Data}

Satellite data from Landsat 8 NASA (satellite launched by National Aeronautics and Space Administration), Sentinel-2A and 2B, as well as Planet Labs Inc. microsatellite, were downloaded from app.satagro.pl (access from 1 January 2019). Likewise, the spectral Normalised Difference Vegetation Index (NDVI) was obtained at app.satagro.pl; it was developed based on data originating from sensors of MODIS (Moderate Resolution Imaging Spectroradiometer). At selected dates, in each variant of the experiment, 50 fixed measurement points were randomly selected and the calculated NDVI, GDD, precipitation parameters were downloaded from app.satagro.pl system. These data were used to assess the nutritional status and condition of plants during vegetation. The measurements were conducted on date 13 of July was selected to demonstrate the effect of foliar fertilization (product 2) on the NDVI index. The spectacular effects of foliar fertilization were usually observed 15 days after the treatment-on 13 of July. Measurements on 31 of August were utilized to show the NDVI differences between the four treatments (F0-F3) after a period of drought starting from 12 of July. On the other hand, on 11 of September (one month before the harvest), the effect of the applied fertilization on the aging and dieback of plants was demonstrated (BBCH 97).

\subsubsection{Landsat 8 Data}

Satellite images with spatial resolution of $15 \mathrm{~m}$ were performed by the satellite Landsat 8 (NASA) every 16 days.

\subsubsection{Sentinel-2A and 2B Data}

Satellite images with spatial resolution of $10 \mathrm{~m}$ were performed by the satellites Sentinel-2A and Sentinel-2B owned by the European Commission and the European Space Agency (ESA) every five days.

\subsubsection{Planet Labs Inc Microsatellite Date}

Satellite images from the microsatellite Planet Labs Inc. (San Francisco, CA, USA), had a resolution of $3 \mathrm{~m}$ and were performed daily throughout the vegetation of maize. 


\subsection{MODIS Data}

Data from the satellite remote sensors of MODIS (Moderate Resolution Imaging Spectroradiometer) installed on Aqua and Terra satellites, were processed by SatAgro (Warsaw, Poland) and presented at app.satagro.pl as the Normalised Difference Vegetation Index (NDVI).

\subsection{Normalised Difference Vegetation Index (NDVI)}

Normalised Difference Vegetation Index (NDVI), enabling assessment of the condition of maize plants, was downloaded from app.satagro.pl. This index was calculated as the ratio of surface reflectance in near-infrared to reflectance in red.

\subsection{Meteroliogical Data}

The mean diurnal temperatures and total diurnal precipitation during maize growth were obtained from the application SatAgro (app.satagro.pl), integrated with the weather station. Downloaded from this application as well, growing degree days (GDD) were calculated as a total of all excess values relative to the mean diurnal temperatures exceeding the threshold temperature $\left(8^{\circ} \mathrm{C}\right)$.

\section{Results and Discussion}

\subsection{Meteorological Conditions during the Growth of Maize}

3.1.1. Growing Degree Days (GDD)

Zea mays has very high temperature requirements, resulting from the origin of this species. The pace with which the consecutive stages of growth occur in maize plants depends on the value of growing degree days (GDD) [21,22]. The base (threshold) temperature for this crop species amounts to approximately $8^{\circ} \mathrm{C}$. On the day that the maize was planted (14 April), the mean diurnal air temperature was $5.6^{\circ} \mathrm{C}$, whereas $\mathrm{GDD}_{0}$ equalled 177.8 (Figure 1), and this value was taken as the basis for the calculations (GDD $=\mathrm{GDD}_{0}-177.8$ ). The value of GDD from the moment maize seeds were planted amounted to over 100 GDD thermal units, constituting the minimum GDD value determining maize seed germination and plant emergence. However, despite the adequate temperature conditions, maize emergence was observed as late as 6 June. This may have been associated with springtime drought directly following the process of maize planting. In the period from maize planting until 2 May there were no significant rainfalls (Figure 2). A single rain event was recorded on 27 April, but the total daily rainfall amounted to $0.8 \mathrm{~mm}$ only.

\subsubsection{Temperature}

Maize plants have significantly higher temperature requirements $(50 \%)$ during the vegetative growth (up to the flowering stage) and generative growth (development of caryopses). However, the value of growing degree days determining normal growth and yield depends on maize variety, FAO number and the intended use of the produce. Planted in the present experiment, maize variety Pioneer, FAO 250, cultivated for its grains, required more than 1250 growing degree units to reach maturity [23]. The values of growing degree days recorded during the vegetation were in the range 0 (planting) to 2108.3 (harvest). It was found that, on 1 August, GDD exceeded 1272.3 (more than minimal GDD value for maize FAO 250 grain production), which determined maturation of the maize (Figure 1). 


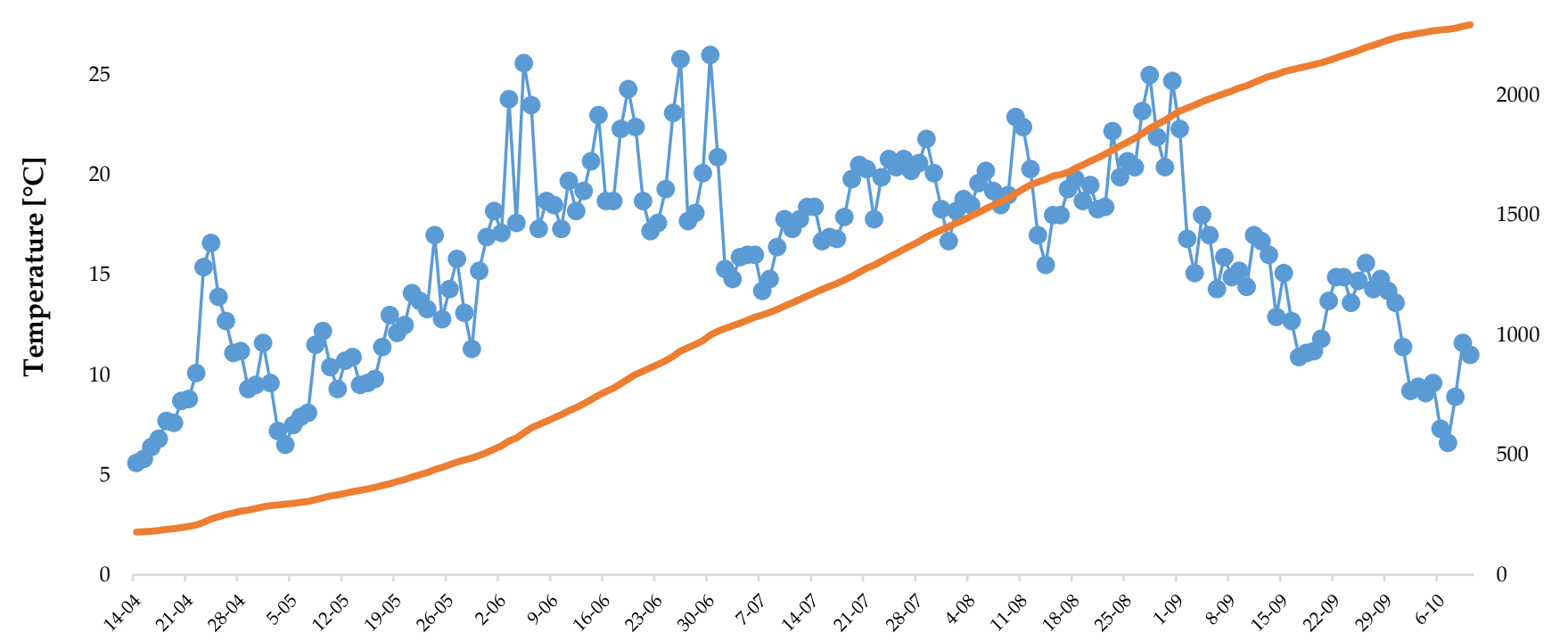

Date

Figure 1. Average daily temperatures from sowing to harvesting of maize and growing degree days (GDD).

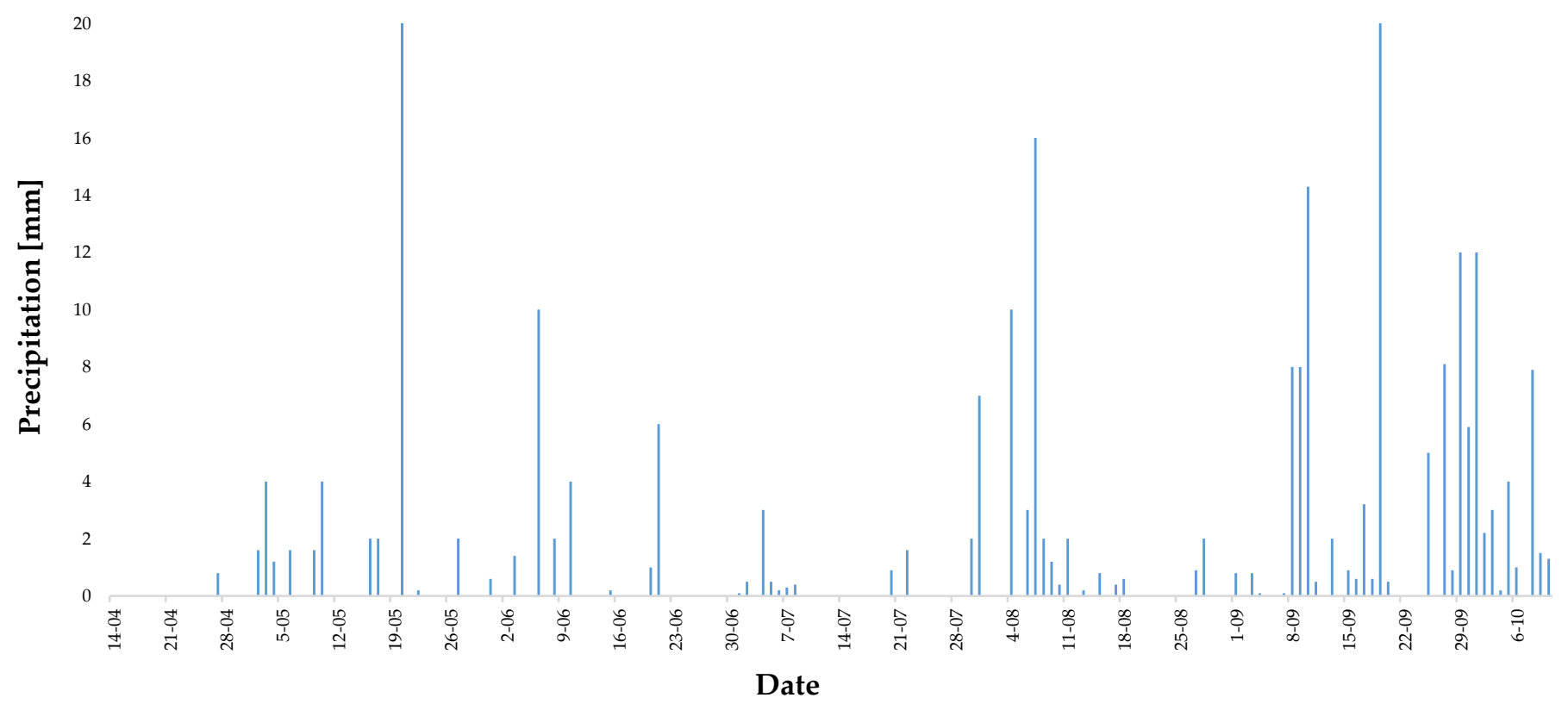

Figure 2. The sum of daily precipitation in the period from sowing to harvesting of maize.

\subsubsection{Precipitation}

Maize plants are characterised by very high water requirement. This is due to its rapid growth and significant increase in its above ground biomass, and despite the relatively low transpiration rate. The requirement in the case of the moderately early variety Pioneer P8589 is in the range of 520-620 mm during the vegetation period [24]. The total precipitation during this period amounted to $238.9 \mathrm{~mm}$ only (Figure 2), which corresponds to slightly more than $38 \%$ of the total water requirement. The dry spells occurring during maize cultivation period, as well as the low total rainfall resulted in relatively low crop yield, ranging from 7.66 to $10.91 \mathrm{t} \cdot \mathrm{ha}^{-1}$ (Figure 8), depending on the fertilisation applied. The yield of this maize variety in optimum weather conditions in Poland on 
average amounts to $14.21 \mathrm{t} \cdot \mathrm{ha}^{-1}$ [25]. Poor yield of maize grain resulting from insufficient availability of water during the vegetation period was also reported by a number of other researchers. Wang et al. [26] demonstrated that increasing frequency and intensity of dry periods occurring in Northeast China during 1961-2017 led to a significant decrease in the yield of maize grain produced. During years with moderate droughts, maize yield was found to decrease by $10.4 \%$ whereas in the years with more dry periods the losses in the yield exceeded $14.0 \%$. On the other hand, Kamara et al. [27] conducted an experiment where various maize genotypes were watered for four weeks after they were planted. Irrigation was thereafter discontinued in the block with the water-deficit treatments (about 27 days before $50 \%$ anthesis) and the crops were allowed to mature on stored moisture. The researchers suggested that the strong water-deficit stress led to $85 \%$ decrease in the yield, compared to the yield obtained in the control (irrigated) facility.

\subsection{Normalised Difference Vegetation Index (NDVI)}

The satellite remote sensing tools, used in the study, made it possible to assess fertilisation technologies applied to maize plants, based on the normalised difference vegetation index (NDVI) observed during the vegetation period. The index directly reflects the condition and nutritional status of plants [28].

Analysis of NDVI values shows that in the period directly following plant emergence until application of foliar fertiliser (F1 and F3 variant), the highest values of NDVI were identified in the case of plants treated with F2 fertiliser variant. These values were most varied on 27 June (directly preceding the foliar feeding) when the mean index in the case of F2 variant plants amounted to 0.639 and was $13.7 \%$ higher compared to F0 plants. The highest values of NDVI in the case of this fertilisation scheme were identified until the moment of activation of the foliar fertiliser applied in the experimental variant F1 and F3 (Figure 3). This resulted from the use of microgranules for precision application into the soil at the time of maize seed planting. This fertiliser contains protein which, owing to the unique mineral base of the amendment, is dissolved in the soil environment; as a result, ammonia nitrogen and amino acids are released [20]. These components directly affect the nutritional status of plants in the initial stages of growth, which is reflected by the values of NDVI.

The first signs reflecting effectiveness of the foliar fertilizer based on calcined bones, boron and molybdenum were observed as early as 13 July (Figures 4 and 5). On that day, the mean values of NDVI for F1 variant maize plants (0.545) were $18.5 \%$ higher compared to the index (0.460) identified for the control plants (F0). Notably, beneficial effects of the complex fertilisation technology applied to maize (F3) were also observed at the time; in this case the highest mean value of NDVI was recorded and amounted to 0.591 (Figure 4). Maize plants treated with foliar fertiliser (experimental variants F1 and F3) were in better condition and presented better nutritional status particularly as regards nitrogen which is contained in the fertiliser. A positive correlation between nitrogen content in plants and NDVI value was also demonstrated by Shaver et al. [29]. Furthermore, the nitrogen contained in the foliar fertiliser enabled synthesis of proteins and porphyrin structure, part of chlorophyll, which also effected greenness of maize leaves [30-32]. Easily available forms of phosphorus contained in the applied foliar fertiliser produced a positive effect on the nutritional status of maize in the experimental variants F1 and F3, which was confirmed by the values of NDVI. A relationship between phosphorus and leaf greenness reflected by NDVI was also reported by Gospodarek et al. [33]. The authors explicitly demonstrated that NDVI value for $A$. pisum plants is correlated to amount of phosphorus fertiliser applied. 


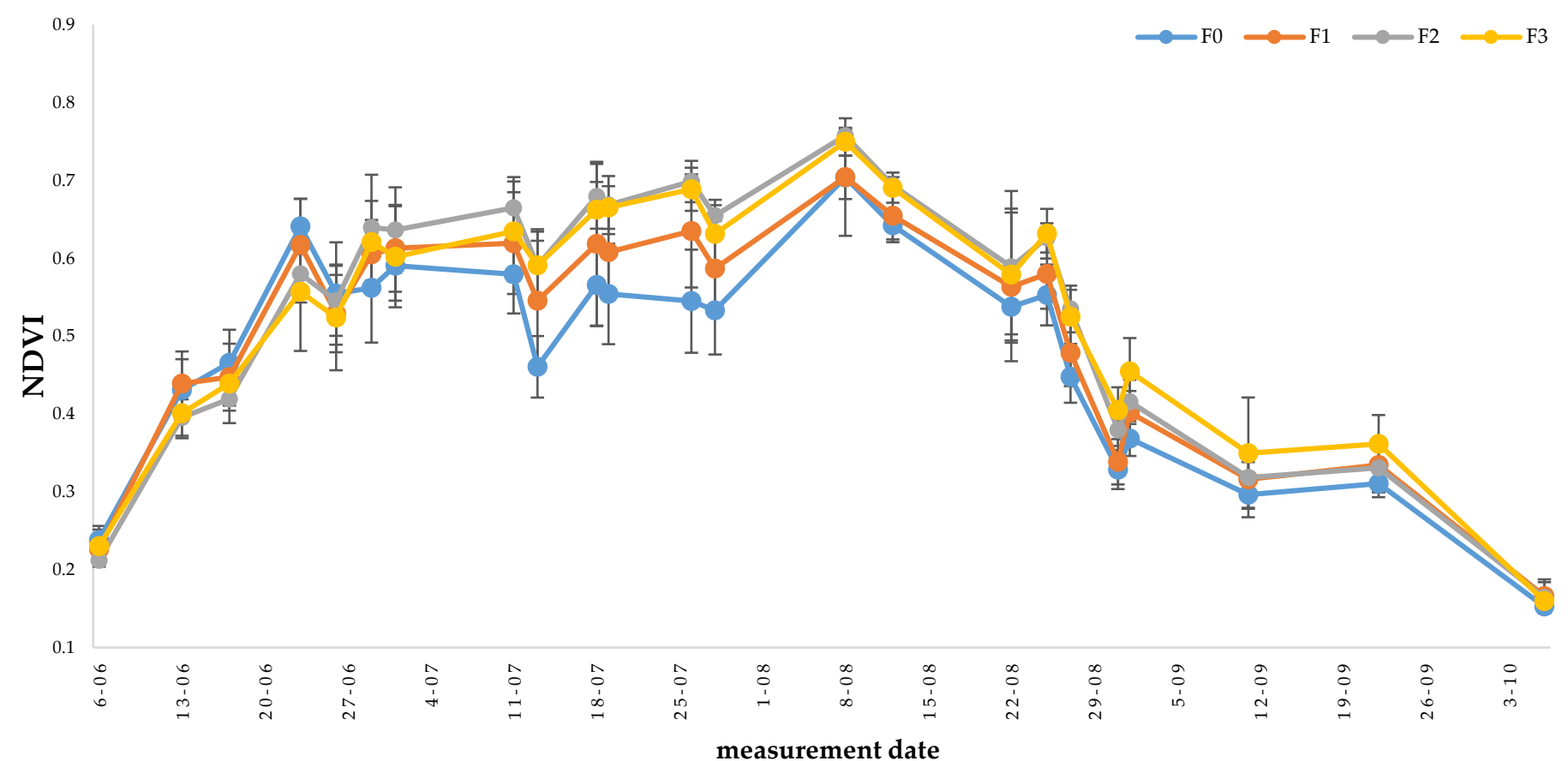

Figure 3. Normalized Difference Vegetation Index (NDVI) during the growing season of maize depending on the fertilization applied (F0 - control; F1—foliar fertilization; F2-localized fertilization: microgranules for precision application into the soil; F3-localized fertilization: microgranules for precision application into the soil with foliar fertilization).

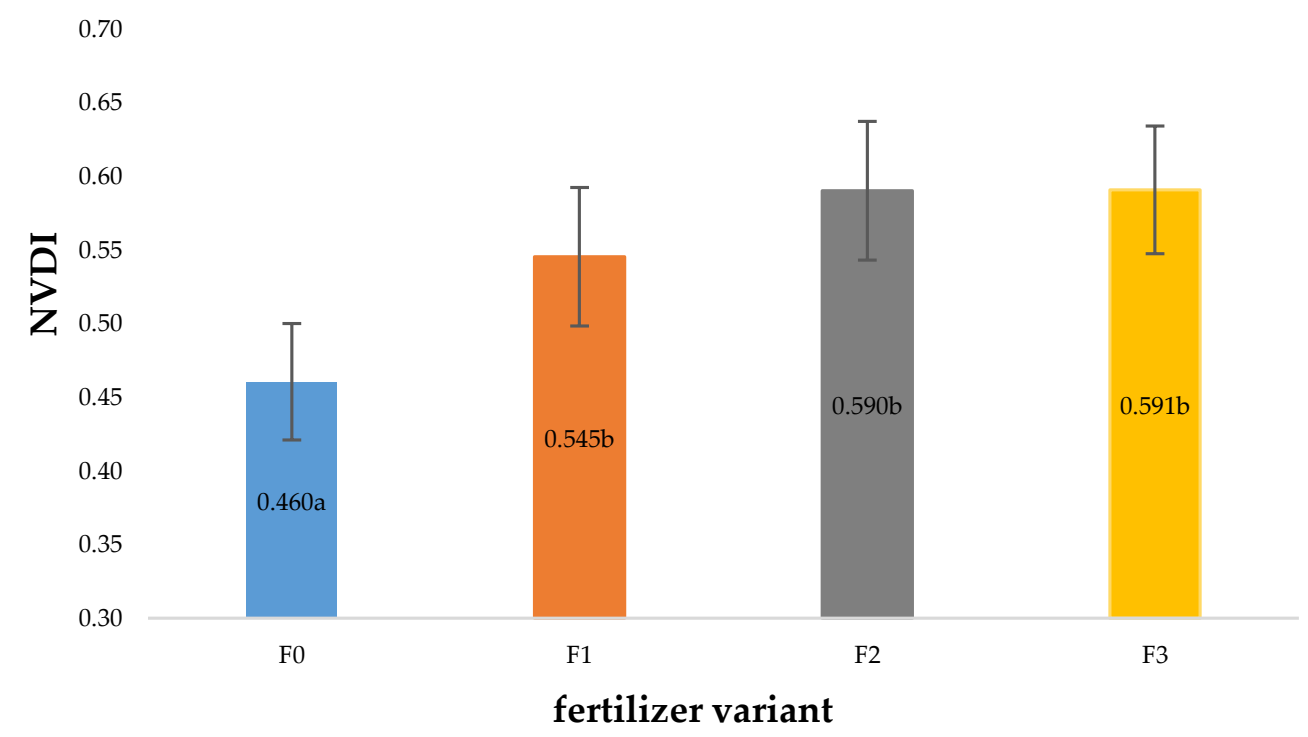

Figure 4. Normalized Difference Vegetation Index (NDVI) on July 13, depending on the fertilization used. Note: F0—control; F1-foliar fertilization; F2-localized fertilization: microgranules for precision application into the soil; F3-localized fertilization: microgranules for precision application into the soil with foliar fertilization. Differences in the results between Normalized Difference Vegetation Index for fertilization variant are marked with different small letters, $p<0.05$. 

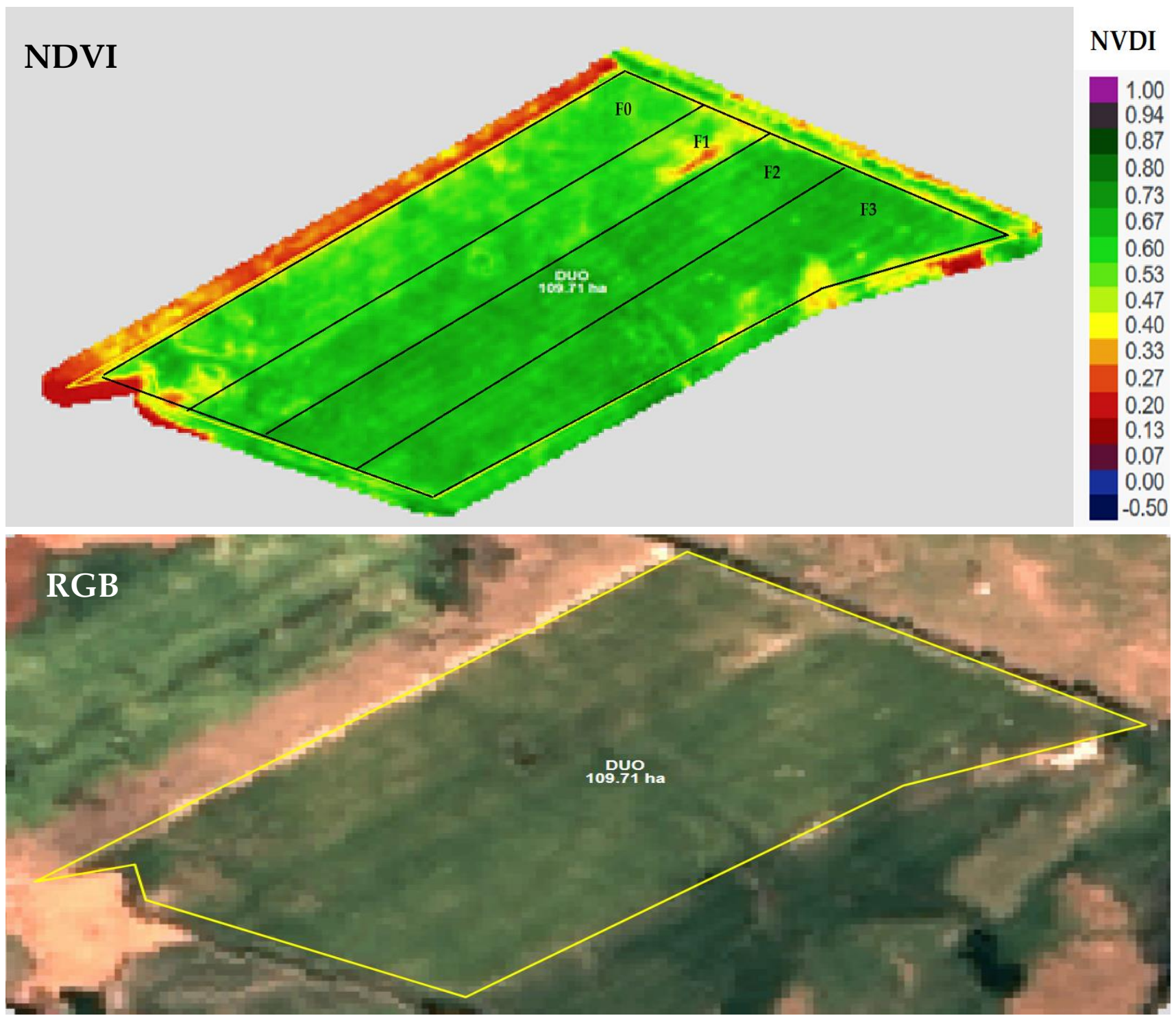

Figure 5. Map with vegetation index (NDVI) and visual (RGB) preview from July 13. Note: F0—control; F1—foliar fertilization; F2 - localized fertilization: microgranules for precision application into the soil; F3-localized fertilization: microgranules for precision application into the soil with foliar fertilization.

The fertilisation variants applied to maize were also correlated with condition of the plants and to NDVI during dry periods observed at the later stages of growth (Figures 6 and 7). The total rainfall from 12 July to 8 September was as low as $6.7 \mathrm{~mm}$. In this period of drought stress, the plants in the experimental variant F3 were found to be in the best condition, which was reflected by the mean value of NDVI. On 31 August (Figures 6A and 7A) the mean NDVI for plants in this variant (F3) was $6.6 \%$ higher compared to the index value identified for the plants in the control variant (F0). Similar relationship between leaf greenness index and the fertilisation scheme applied to maize plants was also observed on 11 September (Figures 6B and 7B). Most possibly this was an effect produced by phosphorus containing microgranules for precision application into the soil used concurrently at the time of maize seed planting. The phosphorus supplied at the initial stage of plant growth promoted development of deep roots as a result of which during the period of water deficit the plants were able to absorb nutrients from deeper layers of soil. Effects of precision fertilisation with phosphorus, promoting development of root system in Zea mays L. were demonstrated by many researchers. Kruczek [34] showed that by placing phosphorus 
fertiliser in the immediate proximity to maize seeds (precision fertilisation) it is possible to stimulate initial plant growth, including development of the root system. Furthermore, foliar fertiliser applied in the experimental variant F3 provided the plants with easily absorbable nutrients, including nitrogen, which improved the plants' tolerance to water deficits. Higher values of NDVI, linked to fertilisation and observed during dry periods, were reported by other researchers in the context of maize [35] and wheat cultivation [36]. Moreover, positive effects of fertilisation with $\mathrm{N}$ on the values of NDVI related to soybean plants during dry periods were demonstrated by Basal and Szabó [37].

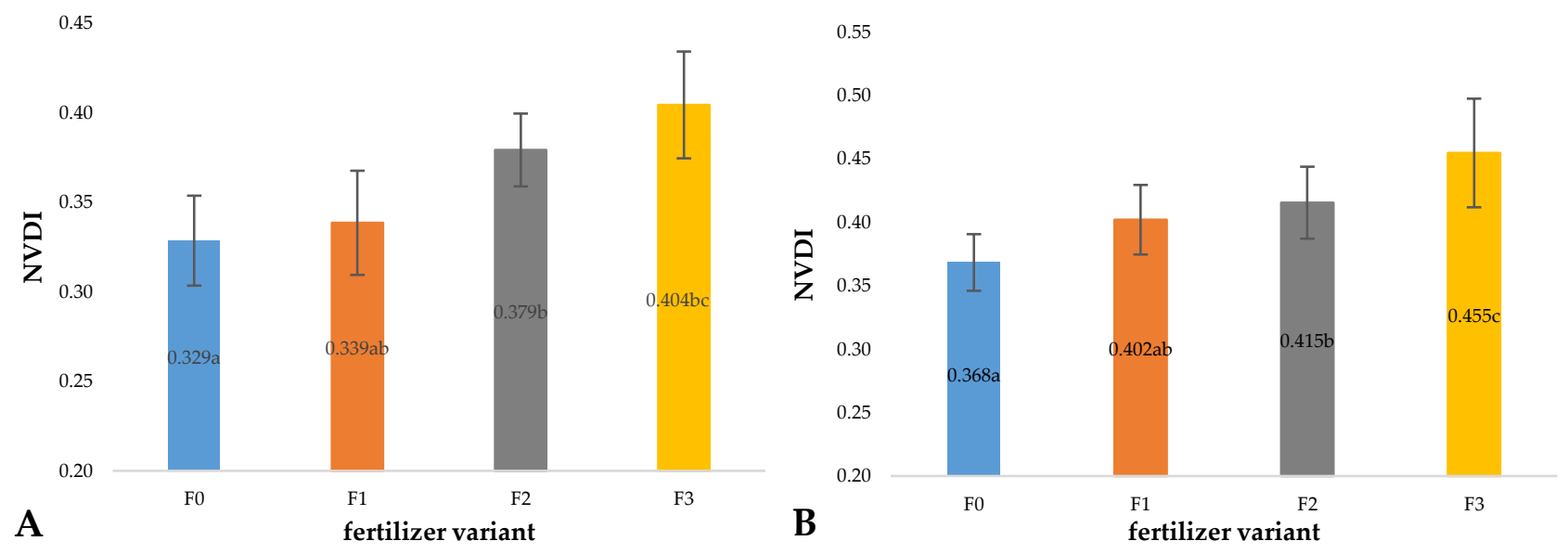

Figure 6. Normalized Difference Vegetation Index (NDVI) recorded August 31 (A) and September 11 (B). Note: F0—control; F1-foliar fertilization; F2-localized fertilization: microgranules for precision application into the soil; F3-localized fertilization: microgranules for precision application into the soil with foliar fertilization. Differences in the results between Normalized Difference Vegetation Index for fertilization variant are marked with different small letters, $p<0.05$.
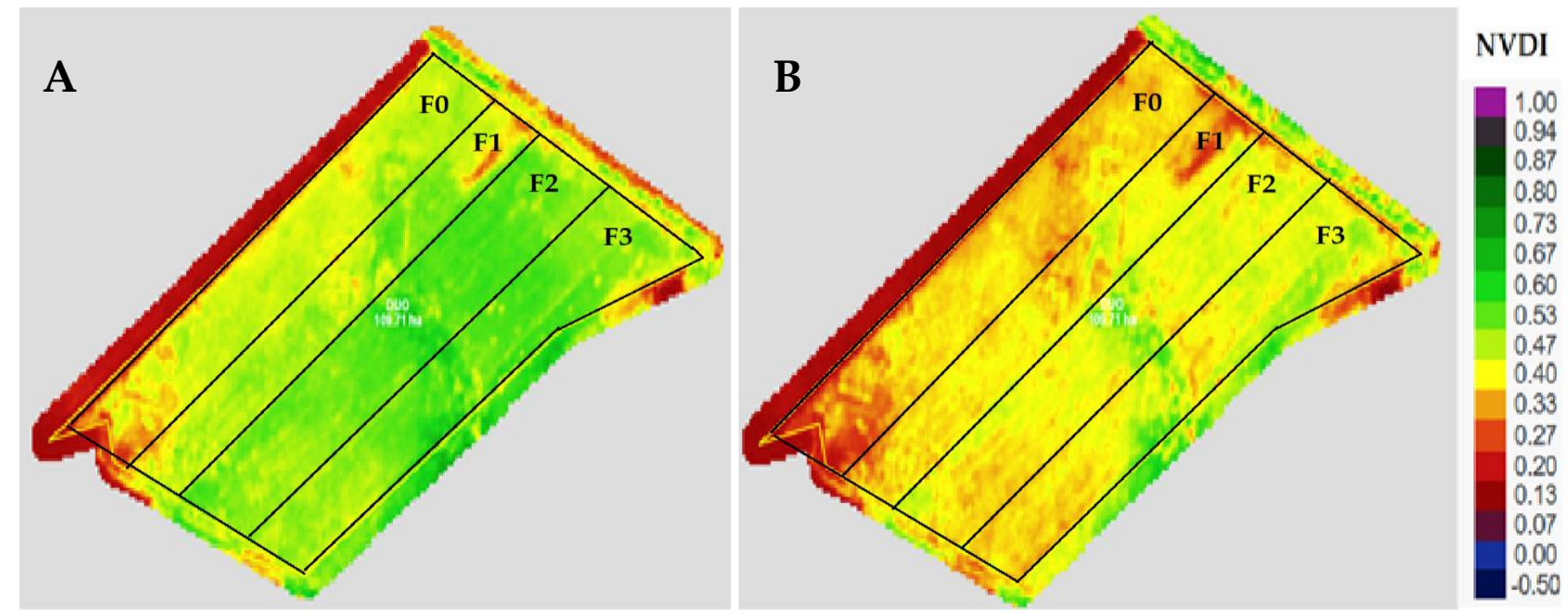

Figure 7. Map with the vegetation index (NDVI) for August 31 (A) and September 11 (B). Note: F0—control; F1—foliar fertilization; F2-localized fertilization: microgranules for precision application into the soil; F3-localized fertilization: microgranules for precision application into the soil with foliar fertilization.

\subsection{Maize Grain Yield}

Fertilisers applied to maize plants affected the final grain yield. As anticipated, the volume of maize grain yield was associated with the use of foliar fertilizer based on calcined bones, boron, and molybdenum, applied in experimental fertilisation variants F1 and F3 (Figure 8). Precision fertilisation (microgranules for application into the soil) was 
additionally applied in F3 variant. This fertiliser, however, produces effects mainly during the early growth stages by stimulating development of roots and vegetative plant parts.

12

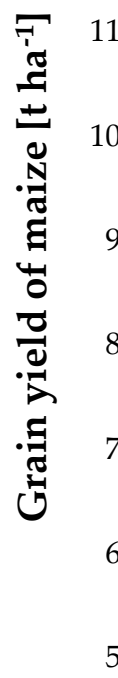

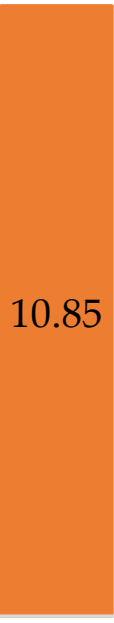

F1

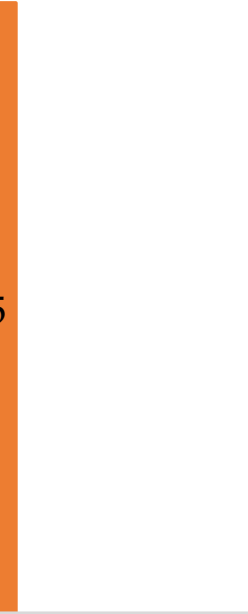

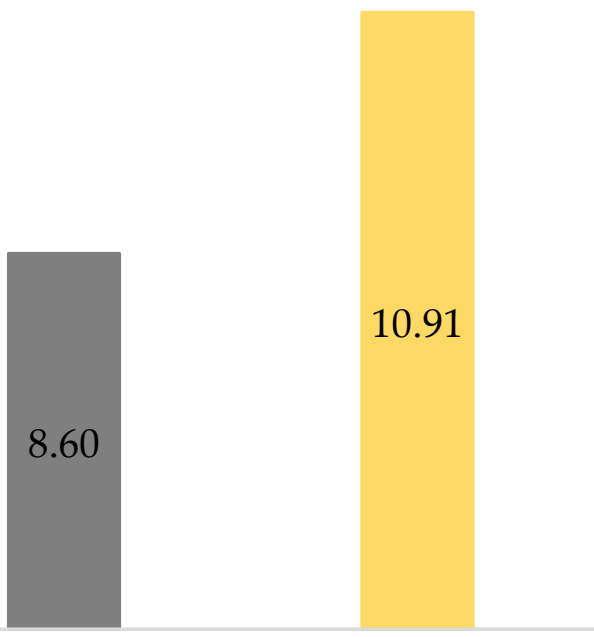

F3

fertilizer variant

Figure 8. Yield of maize grain depending on the fertilization applied (F0—control; F1—foliar fertilization; F2—localized fertilization: microgranules for precision application into the soil; F3-localized fertilization: microgranules for precision application into the soil with foliar fertilization).

The best effects were obtained when the complex fertilisation technology (F3) was used; in this case grain yield recorded, at moisture of $14 \%$, amounted to $10.91 \mathrm{tha}^{-1}$ and was $42.4 \%$ higher compared to the control variant (F0). Similar results $\left(10.85 \mathrm{t} \mathrm{ha}^{-1}\right)$ were recorded in the case of fertilisation variant F1, in which foliar fertilizer based on calcined bones, boron, and molybdenum was applied in addition to the basic fertilisation. Boron provided to maize plants during $\mathrm{BBCH} 16$ stage contributes to metabolism of carbohydrates and stimulates development of the reproductive parts (maize grain) [38]. This fertiliser is a source of easily digestible compounds of phosphorus, which despite the low dosing are quickly absorbed once they reach the surface of leaves. Consequently, they contribute to improved condition of the plants, and most importantly to emergence, development, and maturation of kernels on the cob [39]. Along with this fertiliser, plants receive nitrate nitrogen which is the main factor improving the yield [38]. Effects of fertilisation with these nutrients on maize grain yield were also demonstrated by other researchers. Onasany et al. [40] showed the important role of nitrogen and phosphorus in increasing grain yield in maize production.

\section{Conclusions}

The field experiment was carried out to assess effectiveness of an innovative fertiliser applied to maize plants and based on an alternative source of raw material. The complex technology comprised standard soil amendment as well as microgranules for precision application into the soil concurrent with maize seed planting (starting fertilisation) followed by foliar feeding. During the plant growth, satellite images were taken using satellite remote sensing method, and making it possible to calculate maize leaf greenness (NDVI). The indicator reflected nutritional status of the plants and enabled differentiation of the areas where varied fertilisation patterns were used. The findings show the highest nutritional status of the plants in which the complex fertilization F3 technology was applied. It should be noted that application of localized soil fertilizer alone F2 resulted in the development 
of a deep root system of Zea mays plants which caused in a higher resistance to drought. Moreover, it was shown that the application of foliar fertilizer F1 had the greatest impact on the grain yield. These results correlated with the final maize grain yield, which in the case of this variant was $42.4 \%$ higher than in the control variant.

Supplementary Materials: The following are available online at https:/ /www.mdpi.com/article/10 .3390/agriculture11080754/s1, Table S1: Characteristics of the applied fertilisers.

Author Contributions: Conceptualization, methodology, investigation and writing-original draft, N.M.; Writing—original draft, M.B.; Investigation, O.B. and M.Z.; Formal analysis, J.G.; All authors have read and agreed to the published version of the manuscript.

Funding: This research received no external funding.

Institutional Review Board Statement: Not applicable.

Informed Consent Statement: Not applicable.

Conflicts of Interest: The authors declare no conflict of interest.

\section{References}

1. Stoyanova, Z.; Harizanova, H. Impact of agriculture on water pollution. AGROFOR Int. J. 2019, 4, 111-118. [CrossRef]

2. Rashford, B.S.; Walker, J.A.; Bastian, C.T. Economics of Grassland Conversion to Cropland in the Prairie Pothole Region. Conserv. Biol. 2011, 25, 276-284. [CrossRef]

3. Liaghat, S.; Balasundram, S.K. A Review: The Role of Remote Sensing in Precision Agriculture. Am. J. Agric. Biol. Sci. 2010, 5, 50-55. [CrossRef]

4. Tellaeche, A.; Burgos-Artizzu, X.P.; Pajares, G.; Ribeiro, A.; Quintanilla, C.F. A new vision-based approach to differential spraying in precision agriculture. Comput. Electron. Agric. 2008, 60, 144-155. [CrossRef]

5. Auernhammer, H. Precision farming-The environmental challenge. Comput. Electron. Agric. 2001, 30, 31-43. [CrossRef]

6. Banaszkiewicz, M.; Lewiński, S.; Aleksandrowicz, S.; Woźniak, E.; Kotarba, A.; Krupiński, M. Zastosowanie technik satelitarnych w rolnictwie zrównoważonym-Wybrane przykłady zastosowań. Probl. Inżynierii Rol. 2012, 3, 109-122.

7. Candiago, S.; Remondino, F.; De Giglio, M.; Dubbini, M.; Gattelli, M. Evaluating Multispectral Images and Vegetation Indices for Precision Farming Applications from UAV Images. Remote Sens. 2015, 7, 4026-4047. [CrossRef]

8. Pettorelli, N.; Ryan, S.; Mueller, T.; Bunnefeld, N.; Jedrzejewska, B.; Lima, M.; Kausrud, K. The Normalized Difference Vegetation Index (NDVI): Unforeseen successes in animal ecology. Clim. Res. 2011, 46, 15-27. [CrossRef]

9. Meng, Q.; Cieszewski, C.J.; Madden, M.; Borders, B. A linear mixed-effects model of biomass and volume of trees using Landsat ETM+ images. For. Ecol. Manag. 2007, 244, 93-101. [CrossRef]

10. Flowers, M.; Weisz, R.; Heiniger, R. Quantitative Approaches for Using Color Infrared Photography for Assessing In-Season Nitrogen Status in Winter Wheat. Agron. J. 2003, 95, 1189-1200. [CrossRef]

11. Seelan, S.K.; Laguette, S.; Casady, G.M.; Seielstad, G.A. Remote sensing applications for precision agriculture: A learning community approach. Remote Sens. Environ. 2003, 88, 157-169. [CrossRef]

12. Lloret, F.; Lobo, A.; Estevan, H.; Maisongrande, P.; Vayreda, J.; Terradas, J. Woody plant richness and ndvi response to drought events in catalonian (northeastern spain) forests. Ecology 2007, 88, 2270-2279. [CrossRef] [PubMed]

13. He, Y.; Bo, Y.; De Jong, R.; Li, A.; Zhu, Y.; Cheng, J. Comparison of vegetation phenological metrics extracted from GIMMS NDVIg and MERIS MTCI data sets over China. Int. J. Remote Sens. 2015, 36, 300-317. [CrossRef]

14. Dabrowska-Zielinska, K.; Kogan, F.; Ciolkosz, A.; Gruszczynska, M.; Kowalik, W. Modelling of crop growth conditions and crop yield in Poland using AVHRR-based indices. Int. J. Remote Sens. 2002, 23, 1109-1123. [CrossRef]

15. Dą̧rowska-Zielińska, K.; Ciołkosz, A.; Malińska, A.; Bartold, M. Monitoring of agricultural drought in Poland using data derived from environmental satellite images. Geoinf. Issues 2011, 3, 87-97. [CrossRef]

16. Ciołkosz, A.; Ostrowski, J. Rola teledetekcji w rozpoznaniu i ocenie stanu zasobów odnawialnych w Polsce. Woda Sr. Obsz. Wiej. $2007,7,7-23$.

17. Balawejder, M.; Matłok, N.; Gorzelany, J.; Pieniażek, M.; Antos, P.; Witek, G.; Szostek, M. Foliar Fertilizer Based on Calcined Bones, Boron and Molybdenum-A Study on the Development and Potential Effects on Maize Grain Production. Sustainabilty 2019, 11, 5287. [CrossRef]

18. Matlok, N.; Szostek, M.; Antos, P.; Gajdek, G.; Gorzelany, J.; Bobrecka-Jamro, D.; Balawejder, M. Effect of Foliar and Soil Fertilization with New Products Based on Calcinated Bones on Selected Physiological Parameters of Maize Plants. Appl. Sci. 2020, 10, 2579. [CrossRef]

19. Balawejder, M.; Szostek, M.; Gorzelany, J.; Antos, P.; Witek, G.; Matłok, N. A Study on the Potential Fertilization Effects of Microgranule Fertilizer Based on the Protein and Calcined Bones in Maize Cultivation. Sustainability 2020, 12, 1343. [CrossRef] 
20. Olbrycht, M.; Kołodziej, M.; Bochenek, R.; Przywara, M.; Balawejder, M.; Matłok, N.; Antos, P.; Piątkowski, W.; Antos, D. Mechanism of nutrition activity of a microgranule fertilizer fortified with proteins. BMC Plant Biol. 2020, 20, 126. [CrossRef] [PubMed]

21. Streck, N.A.; Weiss, A.; Xue, Q.; Baenziger, P.S. Improving predictions of developmental stages in winter wheat: A modified Wang and Engel model. Agric. Forest Meteorol. 2003, 115, 139-150. [CrossRef]

22. Dahmardeh, M. Effects of sowing date on the growth and yield of maize cultivars (Zea mays L.) and the growth temperature requirements. Afr. J. Biotechnol. 2012, 11, 12450-12453. [CrossRef]

23. Zaliwski, A.; Górski, T. Prawdopodobieństwo Dojrzewania Kukurydzy-Aplikacja Internetowa. Agric. Eng. 2005, 9, 401-408.

24. Rutkowski, J. Technologia Uprawy Kukurydzy—Od Siewu do Zbioru, Warmińsko-Mazurski Ośrodek Doradztwa Rolniczego z siedzibą w Olsztynie, Olsztyn. 2018. Available online: https:/ / docplayer.pl/111143494-Technologia-uprawy-kukurydzy-odsiewu-do-zbioru.html (accessed on 15 May 2021).

25. Pioneer. Available online: https:/ / www.pioneer.com/pl/products/kukurydza_na_ziarno.html (accessed on 26 July 2021).

26. Wang, C.; Linderholm, H.W.; Song, Y.; Wang, F.; Liu, Y.; Tian, J.; Xu, J.; Song, Y.; Ren, G. Impacts of Drought on Maize and Soybean Production in Northeast China During the Past Five Decades. Int. J. Environ. Res. Public Health 2020, 17, 2459. [CrossRef]

27. Kamara, A.Y.; Menkir, A.; Badu-Apraku, B.; Ibikunle, O. The influence of drought stress on growth, yield and yield components of selected maize genotypes. J. Agric. Sci. 2003, 141, 43-50. [CrossRef]

28. Spitkó, T.; Nagy, Z.; Zt, Z.; Szőke, C.; Berzy, T.; Pintér, J.; Cl, M. Connection between normalized difference vegetation index and yield in maize. Plant Soil Environ. 2016, 62, 293-298. [CrossRef]

29. Shaver, T.M.; Khosla, R.; Westfall, D.G. Evaluation of two crop canopy sensors for nitrogen variability determination in irrigated maize. Precis. Agric. 2011, 12, 892-904. [CrossRef]

30. Hatfield, J.L.; Prueger, J.H. Value of Using Different Vegetative Indices to Quantify Agricultural Crop Characteristics at Different Growth Stages under Varying Management Practices. Remote Sens. 2010, 2, 562-578. [CrossRef]

31. Hunt, E.R.; Doraiswamy, P.C.; McMurtrey, J.E.; Daughtry, C.; Perry, E.M.; Akhmedov, B. A visible band index for remote sensing leaf chlorophyll content at the canopy scale. Int. J. Appl. Earth Obs. Geoinf. 2013, 21, 103-112. [CrossRef]

32. Viña, A.; Gitelson, A.A.; Nguy-Robertson, A.L.; Peng, Y. Comparison of different vegetation indices for the remote assessment of green leaf area index of crops. Remote Sens. Environ. 2011, 115, 3468-3478. [CrossRef]

33. Gospodarek, J.; Klimek-Kopyra, A.; Rusin, M. Suitability of NDVI index to pea condition evaluation at diverse phosphorus fertilization. Ital. J. Agron. 2020, 15, 35-47. [CrossRef]

34. Kruczek, A. Phosphorus Utilization from Fertilizer and Accumulation of Mineral Components in the Initial Stage of Maize Development. Pol. J. Environ. Stud. 2005, 14, 83-91.

35. Saleem, M.F.; Ma, B.L.; Voldeng, H.; Wang, T.-C. Nitrogen nutrition on leaf chlorophyll, canopy reflectance, grain protein and grain yield of wheat varieties with contrasting grain protein concentration. J. Plant Nutr. 2010, 33, 1681-1695. [CrossRef]

36. Mupangwa, W.; Nyagumbo, I.; Mutsamba, E.; Mhlanga, B.; Mataruse, J. Maize responses to reduced tillage, different plant residue mulch and nitrogen fertiliser on granitic sandy soils of Zimbabwe. South Afr. J. Plant Soil 2018, 35, 367-376. [CrossRef]

37. Basal, O.; Szabó, A. The Combined Effect of Drought Stress and Nitrogen Fertilization on Soybean. Agron. 2020, 10, 384. [CrossRef]

38. Lordkaew, S.; Dell, B.; Jamjod, S.; Rerkasem, B. Boron deficiency in maize. Plant Soil 2010, 342, 207-220. [CrossRef]

39. Ahmad, W.; Niaz, A.; Kanwal, S.; Khalid, M. Role of boron in plant growth: A review. J. Agric. Res. 2009, 47, 329-338.

40. Onasanya, R.O.; Aiyelari, O.P.; Onasanya, A.; Oikeh, S.; Nwilene, F.E.; Oyelakin, O.O. Growth and Yield Response of Maize (Zea mays L.) to Different Rates of Nitrogen and Phosphorus Fertilizers in Southern Nigeria. World J. Agric. Sci. $2009,5,400-407$. 